UDC 371.134:355.23

DOI https://doi.org/10.32836/2310-9653-2020-3.14

A. F. Lazutsky, PhD Military Sciences, Associate Professor, Lecturer at the Department of the National Academy of the National Guard of Ukraine

V. A. Romanyuk, PhD Technical Sciences, Associate Professor, Associate Professor at the Department of the National Academy of the National Guard of Ukraine

S. O. Starodubtsev, PhD Military Sciences, Associate Professor, Associate Professor at the Department of the National Academy of the National Guard of Ukraine

\title{
IMPROVEMENT OF PROFESSIONAL TRAINING CADETS OF MILITARY EDUCATIONAL INSTITUTIONS OF MANAGEMENT DAILY ACTIVITIES OF MILITARY SUBUNITS
}

Today, the role of properly and clearly organized command and control of troops is growing significantly as the basis for maintaining their constant combat readiness. Since the commander is responsible for making the right and informed decision, the requirements to the level of his training are certainly growing. The state of combat readiness of a subunits mainly depends on the personal qualities of the commander, that is, on how quickly he, starting to perform official duties, develops a system of his own organizational activities.

At the same time, the military education system is slowly adapting to modern requirements; training programs in military educational institutions do not cover the whole range of issues that the commander has to deal with in his everyday practice. A well-functioning system for managing the day-to-day operations of troops is called upon to prevent a decrease in combat readiness and to help leaders with the greatest efficiency organize their work and the work of subordinate subunits.

The Gantt chart is a kind of standard in the field of project management, because it is with its help that it becomes possible to show the structure of the implementation of all stages of the project clearly. What is a Gantt chart for? Considering that most people are visuals, the diagram makes it possible to solve one of the main tasks and show the personnel what to work on, what resources to use in the process, and at what speed to perform certain tasks. All information is presented in a compressed form, without the use of confusing tables and a huge amount of text. Moreover, the essence is clear and understandable to all project participants without exception.

Using a chart greatly simplifies the management of small-scale projects and makes it possible to always keep subordinate activities under control.

The schedule is developed by the headquarters of the leadership, approved by the head of the exercise and communicated to the relevant performers.

The initial data for the organization of the exercises are: the purpose (training, research), the time of the training and its duration, the composition of the military personnel, the students studying the norms for the use of motor resources (fuels and lubricants), ammunition and imitation equipment.

Consider the rules for constructing a Gantt chart in accordance with our source data and create it in the Microsoft Excel table processor.

Key words: combat readiness, military education, management of daily activities, Gantt chart.

А. Ф. Лазутський, В. А. Романюк, С. О. Стародубцев. Застосування діаграми Ганта курсантами Національної академії Національної гвардії України при вивченні дисципліни управління повсякденною діяльністю підрозділів

У сучасних умовах значно підвищується роль правильно й чітко організованого управління військами як основи підтримки їхньої постійної бойової готовності. Оскільки відповідальність за ухвалення правильного й обтрунтованого рішення несе командир, безумовно, зростають вимоги до рівня його підготовки. Стан боєздатності підрозділу багато в чому залежить від особистих якостей командира, тобто від того, наскільки швидко він, приступаючи до виконання службових обов'язків, виробить систему власної організаторської діяльності.

Водночас система військової освіти ще повільно адаптується до сучасних вимог, програми підготовки у військових навчальних закладах не охоплюють усього комплексу питань, з якими доводиться стикатися командирові в повсякденній практиці: не допустити зниження бойової готовності, допомогти керівникам, із найбільшою ефективністю організувати свою роботу й роботу підпорядкованих підрозділів - на все че потрібна добре влагоджена система управління повсякденною діяльністю військ.

Розглянутий у роботі графік Ганта є своєрідним стандартом у галузі управління проєктами, адже саме з його допомогою з'являється можсливість показати структуру виконання всіх етапів проєкту наочно. Для чого потрібна діаграма Ганта? 3 урахуванням того, що велика частина людей є візуалами, діаграма дає можливість розв'язати одне з основних завдань і показати особовому складу, над чим слід прачювати, які ресурси застосовувати в проиесі й з якою швидкістю виконувати ті чи інші завдання. Вся інформація подається в стислому вигляді, без використання заплутаних таблиць і величезної кількості тексту. Водночас суть ясна й зрозуміла всім без винятку учасникам проєкту.

Використання діаграми значно спрощує управління проєктами невеликих масштабів і дає можливість завжди тримати діяльність підлеглих під контролем.

Ключові слова: бойова готовність, військова освіта, управління повсякденною діяльністю, графік Ганта.

(C) A. F. Lazutsky, V. A. Romanyuk, S. O. Starodubtsev, 2020 
Formulation of the problem. In connection with the further development of the National Guard of Ukraine, the system of military education is faced with the task of improving it, the main purpose of which is to prepare a military specialist who is able to carry out combat and training tasks of the daily activities of troops, manage the combat training of subordinates, and properly develop educational work with them, improve their professional skills, deepen their military special and pedagogical knowledge, improve culture and methodological training.

The officer has always been and is the bearer of the idea of serving his homeland, fidelity to military duty, the spiritual and military traditions of the National Guard. It is the officer who forms in his subordinates a sense of love and respect for the state, its past and present, and pride in belonging to the National Guard. As a result, even in the early stages of training an officer, special attention should be paid to the formation of his competencies related to professional activities in military service, especially with regard to the management of the daily operations of subunits.

However, the analysis of military internships, reviews from the troops shows that a significant part of the graduates of military educational institutions are not adequately prepared to work in their specialty. These characteristic shortcomings are noted: a low level of methodological knowledge, skills, difficulties in practical activities in organizing daily activities, inability to develop documents for planning combat training, keep records of combat training in the subunit [1, p. 6; 2, p. 392].

The results obtained indicate shortcomings in the training of future officers in this area through the traditional underestimation of the need for an integral part of the training of future military specialists.

Thus, the existing system of officer training does not sufficiently take into account new trends and requirements for the training of military personnel, requires certain changes to be made in the organization and implementation of the educational process of military educational institutions $[1$, p. $6 ; 2$, p. 393; 3, p. 36].

Analysis of recent research and publications. High requirements for the training of officers is the main guarantee of the successful functioning of any military structure, the main component of which are specialists with higher military special education. In the process of training military specialists, special attention should be paid to the formation of competencies in cadets for organizational, managerial and operational activities that determine the engineering and operational skills of officers and military specialists.

The main task of training officers in military universities is to ensure that the future officer is fully consistent with the updated the National Guard of Ukraine and the realities of modern society. At the same time, the current stage of the military education system is characterized by the search and implementation of ways to ensure a radical increase in the professionalism and general culture of military specialists. Since the effective solution of the tasks set before the Armed Forces is mainly determined by the quality of training of officer personnel, the problem of managing the formation of their professional competence becomes an urgent area of pedagogical research $[1$, p. $7 ; 2$, p. 390; 4, p. 474].

So, professional competence is professional preparedness and the ability of the subject of labor (specialist or team) to perform tasks and responsibilities of everyday activities, is considered as the level of personal ownership of the relevant competence, determines the willingness of the person to carry out motivated actions that demonstrate the degree of assimilation of educational competence. Professional competence can be expressed by an assessment, a special sign characterizing the case of an ideal normative certificate by a given cadet or a group of educational participants $[3$, p. $34 ; 4$, p. $475 ; 6$, p. 35$]$.

Professional competence is a regulatory requirement for the level of preparedness of a participant in the educational process, reflects the quality of assimilation of the content of education as a result of activities. Professional competency structures all educational areas, subjects and combines them into a single, coherent picture. The quality of development assumes the existence of such social experience, which, firstly, is able to manage self-education for the production of new author's interpretations of the information that a participant already has in the process of information, and secondly, does not lose its significance outside the educational activity itself [3, p. 33; 5, p. 386; 6, p. 37].

One of the urgent tasks of increasing the level of preparedness of cadets as heads of structural divisions is targeted daily activities in training them to carry out and carry out activities for daily activities, primarily to support combat and mobilization readiness, military discipline, law and order, military service, and the organization of combat training, which requires from the commanders, officers of the unit deep and comprehensive military-professional and methodological knowledge, skills, abilities, features to manage subordinate units. The result of the combat mission depends on the quality of the management of units. Unit management is the activity of commanders, chiefs and other management bodies in managing the relevant units in the preparation and implementation of tasks.

Today, the management of subunits is a complex process, including: the work of commanders and staffs and is a continuous production, collection, study and synthesis of environmental data; decision-making; bringing tasks to subordinate subunits; battle planning; organization of maintaining continuous interaction; organization and implementation of measures to support combat readiness, combat readiness and coordination of subunits; the organization of educational work, management systems, direct supervision of the preparation of units for hostilities, constant monitoring of where the implementation of tasks and support for subordinates [4, p. 478; 5, p. 384; 7, p. 139; 8, p. 266-268].

The purpose of the article is to develop proposals for improving the training of cadets in the discipline "Management of daily activities of military subunits". 
Research results. In modern conditions, the pace of informatization of society is growing, it is manifested in the penetration of new information technologies into various areas of human activity, the modification of certain professional functions, the emergence of new types of professional activity, require a meaningful and technological restructuring of the educational system in order to train qualified specialists.

In the context of a significant modernization of weapons and military equipment, weapons of warfare and the specifics of the combat use of units and divisions of the National Guard of Ukraine, due to the pace of development of scientific and technological progress, the processes of informatization of society, an increase in the share of the use of new information technologies and the role of information flows in military-combat activity must have a high level of readiness for the implementation of professional functions, freely navigate the information space of modern society.

The informatization of modern society is characterized by the increasing use of information resources for various areas of professional activity, suggesting radical changes in the content and technology of its organization.

At the same time, the informatization of the military combat activity of military specialists, as representatives of a power institution in the state structure, is primarily associated with the creation and provision of the necessary level of information equipment in order to qualitatively solve professional tasks in various conditions of the operational situation.

Therefore, the features of modern realities as one of the priority tasks facing the military education system determine the search for ways and means of improving the professional training of cadets of military universities of the NGU in the context of large-scale informatization of society, the NGU, and the military education system.

It is obvious that under the conditions of informatization, the priority value of the education system as a whole and the military, in particular, is to prepare a specialist for activities in the information society, to create professional readiness for its independent organization, actualizes the informational orientation of the educational system, and directs its vector towards informatization.

In fact, informatization of education should be considered as a process of changing the content, forms and methods of professional training of future specialists in the conditions of educational institutions of higher education to innovative educational routes.

Today, the vector of informatization of military education should be aimed at achieving the following goals: improving the level of professional training of military specialists with the help of information technologies in terms of carrying out a set of organizational, methodological and information-resource procedures; creating conditions for improving the quality of the educational process in a military university through the introduction of innovative methods and forms of training based on modern information technologies.

Therefore, the development and implementation of information technology takes priority in the education system, expands the boundaries of the organizational and methodological capabilities of the educational system itself.

Among the directions for the creation and implementation of information technologies in the training system for military specialists in recent years, the priority is the use of information technologies that are universal in the educational process (text editors, graphic software products, database management systems, spreadsheet processors, modeling systems, etc.

The widespread use of these technologies is due to the fact that they:

1) do not require special software in the process of developing the learning environment, which in turn allows you to focus on the preparation of methodological support in terms of designing the content and system of tasks performed in this environment;

2) the developed methodical materials can be used in the course of work with any type of hardware (computer) owing to the fact that the methodical materials developed by the teacher are compatible with new versions of information technologies.

The use of asynchronous tools, which include: e-mail with the ability to automatically send information, program modules that allow you to assess the level of theoretical knowledge of cadets (for example, the "My test" program module), do not require a permanent network connection between the subjects of information exchange, the "Gantt chart" is one of the most popular tools for illustrating the schedule in project management.

The Gantt chart is a kind of standard in the field of project management, because it is with its help that it becomes possible to show the structure of the implementation of all stages of the project clearly. What is a Gantt chart for? Considering that most people are visuals, the diagram makes it possible to solve one of the main tasks and show the personnel what to work on, what resources to use in the process, and at what speed to perform certain tasks. All information is presented in a compressed form, without the use of confusing tables and a huge amount of text. Moreover, the essence is clear and understandable to all project participants without exception.

Using a chart greatly simplifies the management of small-scale projects and makes it possible to always keep subordinate activities under control.

Gantt chart of any complexity can be easily built using programs such as: SchedRoll; Gantt Designer; Minjet JCVGantt Pro; Microsoft Project and many others. 
In these programs, all work performed is considered as a logically ordered operation. A program operation is usually seen as work that takes time and resources to complete. Most of the above programs come for a fee. The price range is from 2 thousand UAH for an annual license for one workplace, up to 120 thousand UAH per year for the creation and maintenance of a licensed server for a large company.

Moreover, most programs are aimed at solving marketing problems and building business processes. As a rule, the described processes in these programs are the same and do not change dramatically from project to project. In our case, it is proposed to apply the Gantt method in developing a calendar plan for preparing for tactical and special exercises using the Microsoft Excel program.

Thus, the use of the proposed approach will make it possible to break down a difficult task into several sub-tasks, and will allow for the involvement of specialists in specific tactics in organizing tactical and special exercises. Designed graphics can be issued using standard software packages and simple applications does not require additional training of personnel. Let us consider the functioning of this approach as an example of preparing the unit for tactical-special exercises, as one of the main components of the combat training of the unit, in turn, is a component of the daily activities of the troops.

Management of daily activities should be prompt, solid, high-quality, flexible and continuous.

The basis of the MDA is the planning of time and work of the commander and governing bodies.

Training is carried out under the direct supervision of the appropriate commander and begins no later than one and a half months before the beginning of regimental exercises, and for a month - battalion.

Preparation is carried out according to the schedule, which provides for the following:

1) the definition and refinement of the source data for training;

2) the deadline for developing the training documents and the persons responsible for this;

3) the time of reconnaissance of the training area;

4) the necessary measures to prepare the leadership apparatus and intermediaries, staffs and troops for training, as well as to check the readiness of command posts;

5) measures for the preparation of the rear, its period, the creation of the necessary reserves of material resources, the persons responsible for this;

6) a list of the main activities for the preparation of the training area, equipment of management control centers, deployment of communications, command and control services, deadlines and responsible persons.

The schedule is developed by the headquarters of the leadership, approved by the head of the exercise and communicated to the relevant performers.

The initial data for the organization of the exercises are: the purpose (training, research), the time of the training and its duration, the composition of the military personnel, the students studying the norms for the use of motor resources (fuels and lubricants), ammunition and imitation equipment.

Consider the rules for constructing a Gantt chart in accordance with our source data and create it in the Microsoft Excel table processor.

In order to build a graph, you will need the following data: the coordinates of all data sets (where each of the columns should start from) the name of each stage; the duration of each stage (Fig. 1).

\begin{tabular}{|c|c|c|c|c|}
\hline$\Delta$ & A & B & c & D \\
\hline 1 & Tasks & Date & Duration & \\
\hline 2 & Understanding the topic of exercise & $\mathbf{1}_{1}^{1}$ & 1 & \\
\hline 3 & Determining the goals of the stages, educational issues & $1_{1}^{1}$ & 2 & \\
\hline 4 & $\begin{array}{l}\text { Clarification of the composition of the troops involved } \\
\text { in the exercises and the duration of the exercises }\end{array}$ & $\mathbf{1}_{1}^{1}$ & 2 & \\
\hline 5 & $\begin{array}{l}\text { Determination of the norms of consumption of motor } \\
\text { resources, imitation and other material and technical } \\
\text { means necessary for conducting exercises }\end{array}$ & 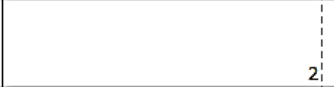 & 2 & \\
\hline 6 & Definition of the design of exercises & $4 !$ & 4 & \\
\hline 7 & $\begin{array}{l}\text { Determining the composition of the manual, } \\
\text { intermediaries and research groups. }\end{array}$ & 3! & 2 & \\
\hline
\end{tabular}

Fig. 1. Data collection

So, we know the purpose of planning and the key data on the basis of which we will build the schedule. Now in the window of the tabular processor we need to go to the "Insert> Chart" section, and then click on the "Ruled." We need not ordinary, but accumulated, because only it provides the second row of data, which in our case will be the main (fig. 2).

We erase everything superfluous in order to do this. Special tools are provided in the program. In the diagram that appears on the screen, you need to move the mouse cursor over the blue bar, right-click on it and select in the menu "Data series format" A window will be displayed, in which you need to go to the "Fill" item and select the "No fill" option. "Reverse Category Order." After that, the diagram will look as follows (Fig. 3). 


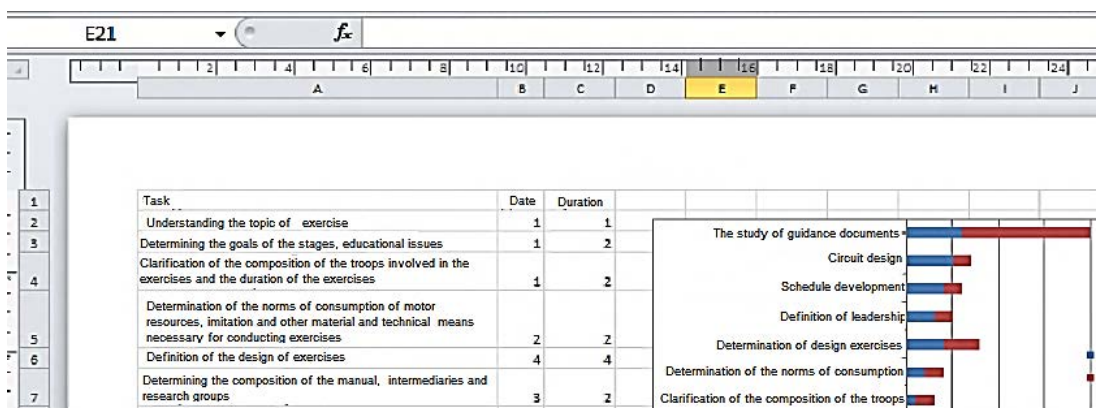

Fig. 2. Formation layout

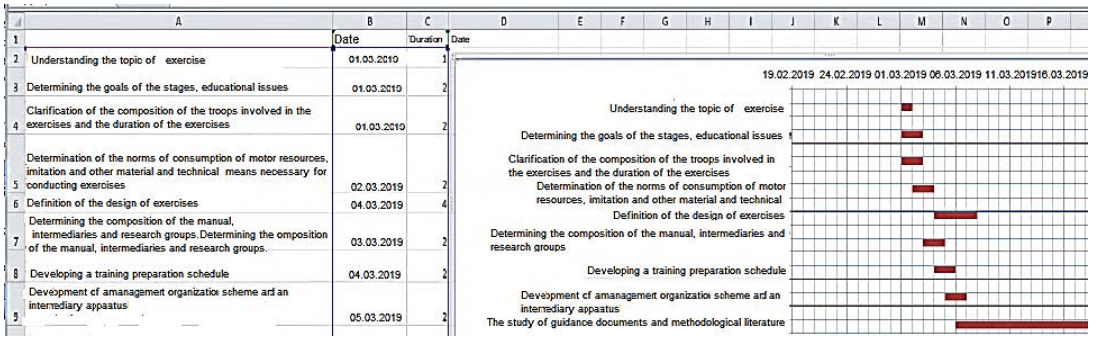

Fig. 3. Previous scheme

Here we can set the price of the main divisions (this is convenient in cases where, for example, work on the project will continue for several weeks or months). In our case, it is more convenient to leave the default values.

At the final stage, the electronic model of the course of preparation for exercises will have the form (Fig. 4).

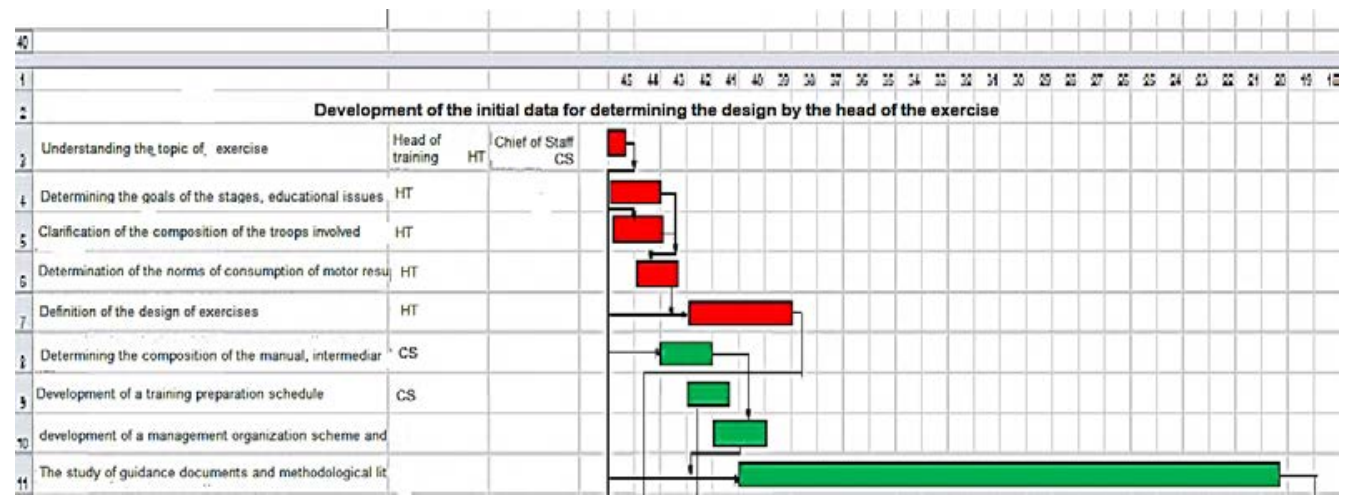

Fig. 4. Electronic model of preparation for exercises

Conclusions and prospects for further research. The success of solving the tasks facing the commanders of units and subunits, largely depends on the quantitative justification of the various solutions and the choice of the optimal one, which corresponds to the real situation and takes into account possible consequences.

The use of the software specified in the work allows us to quickly solve the problems of high-quality tactical training and, in general, combat training, as well as greatly facilitate the management of combat training of units and subunits. The effectiveness of combat training is increased.

The advantages of network planning and management models ensure timely adjustments to the management process and the work of various management bodies, effective prediction of the future and proper impact on the progress of work. Necessary conditions are also provided for the application of experience, human creativity at the stages of setting goals, adjusting the course of their solution and evaluating the final results.

Cadets who have the skills to work with these programs spend less time joining a post and have more opportunities for promotion. 


\section{Bibliography:}

1. Тогочинський О.М., Флорін О.П. Шляхи вдосконалення підготовки курсантів з дисципліни «Управління повсякденною діяльністю підрозділів» для потреб внутрішніх військ МВС України. Збірник наукових праць Академії внутрішніх військ МВС України. 2007. № 1-2 (9-10). С. 5-9.

2. Воробьев Г.В., Дочкин С.А., Костарев С.В., Рябоконь Е.А. Совершенствование профессиональнопедагогической подготовки курсантов военных вузов. Сибирский педагогический журнал. 2008. № 7. С. 389-395.

3. Кириллов Ю.Ф. О некоторых аспектах управления повседневной деятельностью войск. Военная мысль. 1999. № 6 (11-12). С. 32-38.

4. Косолап А.В. Профессиональная компетентность курсантов как результат военно-профессиональной подготовки в военном институте внутренних войск МВД России. Современныле исследования социальных проблем : электронный научный журнал. 2015. № 6 (50). С. 473-481.

5. Рязанов С.А., Тухватуллин И.И., Яцук К.В. Управление подразделениями. Молодой ученьй. 2016. № 25. C. 383-386. URL: https://moluch.ru/archive/129/35715/ (дата звернення: 28.02.2019).

6. Курманалиев Н.Р. Модель развития управленческой компетентности курсантов военного ВУЗа. Вестник КазНПУ. 2014. С. 34-40.

7. Супчинский О.П., Капустьян М.Ф. Комплексный подход при организации и планировании производственных процессов на основе сетевого планирования и «облачных технологий». Омский научный вестник. Машиностроение и машиноведение. 2014. № 3 (133). С. 138-142.

8. Управління повсякденною діяльністю частин Національної гвардії України : навчальний посібник / І.Ф. Ролін, О.П. Флорін, В.І. Тробюк ; за ред. С.Т. Полторака. Харків : НА НГ України, 2014. 383 с.

\section{References:}

1. Tohochynskyy O.M. Shlyakhy vdoskonalennya pidhotovky kursantiv z dystsypliny "Upravlinnya povsyakdennoyu diyalnistyu pidrozdiliv" dlya potreb vnutrishnikh viysk MVS Ukrayiny [Ways to improve the training of cadets from the discipline «Management of daily activities of units» for the needs of internal troops of the Ministry of Internal Affairs of Ukraine]. Zbirnyk naukovykh prats Akademiyi vnutrishnikh viysk MVS Ukrayiny [The digest of scientific works of the Academy of Internal Troops of the Ministry of Internal Affairs of Ukraine], dated 2007, № 1 - 2 (9 - 10), P. 5-9. [in Ukrainian]

2. V. Vorobyev, S. A. Dochkin, S. V. Kostarev, Ye. A. Ryabokon Sovershenstvovaniye professionalno - pedagogicheskoy podgotovki kursantov voyennykh vuzov [Improving the professional - pedagogical training of cadets of military universities] Sibirskiy pedagogicheskiy zhurnal [Siberian Pedagogical Journal], dated 2008, № 7, P. 389 - 359. [in Russian]

3. Kirillov Y.F. O nekotorykh aspektakh upravleniya povsednevnoy deyatelnostyu voysk [On some aspects of the management of the daily activities of the troops] Voyennaya mysl [Military thought], dated 1999, № 6 (11-12), P. 32-38 [in Russian]

4. Kosolap A.V. Professionalnaya kompetentnost kursantov kak rezultat voyenno-professionalnoy podgotovki v voyennom institute vnutrennikh voysk MVD Rossii [Professional competence of cadets as a result of military vocational training at the military institute of internal troops of the Ministry of Internal Affairs of Russia] Sovremennyye issledovaniya sotsialnykh problem (elektronnyy nauchnyy zhurnal [Modern research of social problems (electronic scientific journal)] ], dated 2015, № 6 (50), P. 473-481 [in Russian]

5. Ryazanov S. A., Tuhvatullin I. I., Yatsuk K. V. Upravleniye podrazdeleniyami [Management of divisions] Molodoy uchenyy [Young Scientist] dated 2016, № 25, P. 383 -386. URL https://moluch.ru/archive/129/35715/ [in Russian]

6. Kurmanaliev N.R. Model razvitiya upravlencheskoy kompetentnosti kursantov voyennogo VUZa [Model of development of managerial competence of cadets of a military university] Vestnik KazNPU [Bulletin of KazNPU], dated 2014, P. 34-40 [in Russian]

7. Supchinsky O.P., Kapustyan M.F. Kompleksnyy podkhod pri organizatsii i planirovanii proizvodstvennykh protsessov na osnove setevogo planirovaniya i «oblachnykh tekhnologiy» [An integrated approach to the organization and planning of production processes based on network planning and «cloud technologies»] Omskiy nauchnyy vestnik. Mashinostroyeniye i mashinovedeniye [Omsk Scientific Herald. Mechanical Engineering and Machine Science], dated 2014, № 3 (133), P. 138-142 [in Russian]

8. Rolin I.F Florin., A.P., Trobuk V.I. Upravlinnya povsyakdennoyu diyal'nistyu chastyn Natsionalnoyi hvardiyi Ukrayiny [Management of daily activities of parts of the National Guard of Ukraine] navch. posib. [teaching manual], dated 2014, p. 383 [in Ukrainian] 